\title{
Assessment of Monetary Policies of United Kingdom During Margaret Thatcher's Period \\ Yihang Ge
}

No.29, Xueyuan Road, Haidian District, Beijing, China

angela@cas-harbour.org

Keywords: Monetarism, Thatcher's reform, Assessment.

Abstract. The academic background of this paper is under Keynesian economics and monetarism economics. The purpose is to show British government's monetary policies during Margaret Thatcher's period. There are also short introduction of monetarism and assessment of Thatcher's policies in this paper. Thatcher's reform indeed brought benefit to Britain a lot, however, it caused a series of problems such as unemployment and division between rich and poor. Her courage and perseverance might be helpful to our politicians' reform today. But her policies should be thought twice before applying.

\section{Introduction}

Keynesian policies was used by United Kingdom after World War II and it lost its magic but made United Kingdom struggle in stagflation. Monetarism economists proposed their ideas to control the inflation and let unemployment rate back to its natural rate. Thatcher, as the prime minster of United Kingdom during 1979 to 1990, drove a serious reform based on the theory of monetarism. She cut down enormous government spending and pushed privatization of many enterprises. Those policies led to both achievements and problems. This paper analyzes advantages and disadvantages of theses policies, as well as makes discussion on how to apply them.

\section{Overview of Monetary Policies in UK}

After World War II, many countries, including United Kingdom were using Keynesian. It indeed brought economic prosperity to the United Kingdom, especially between 1951 and 1964.

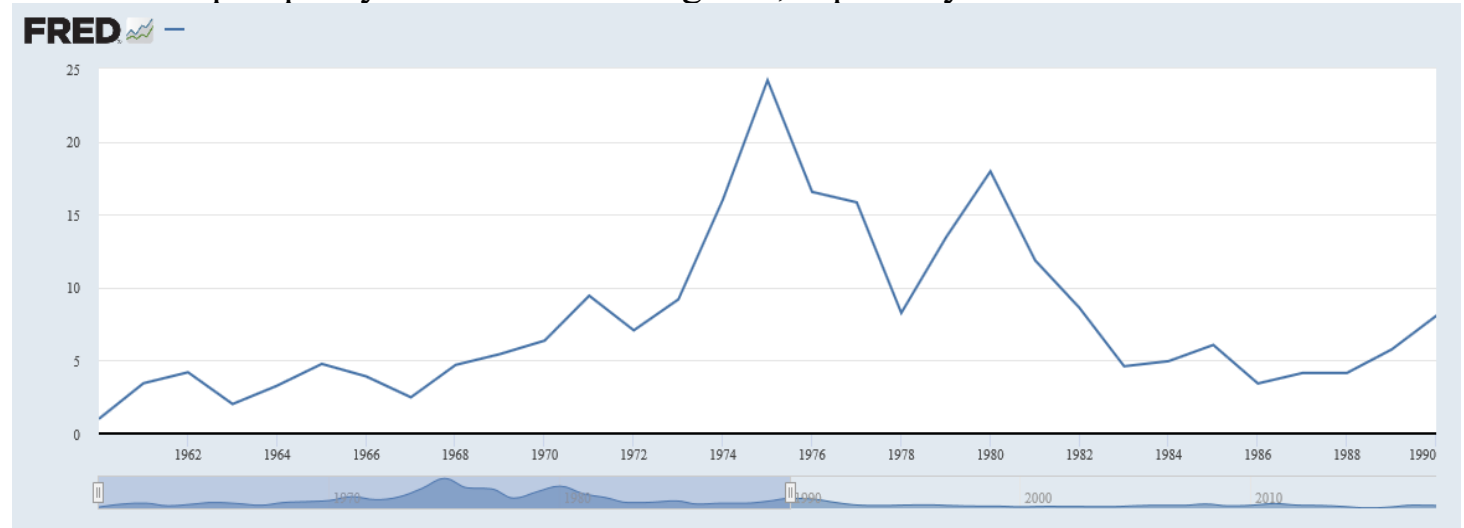

Fig. 1. The inflation rate of United kingdom[1] 


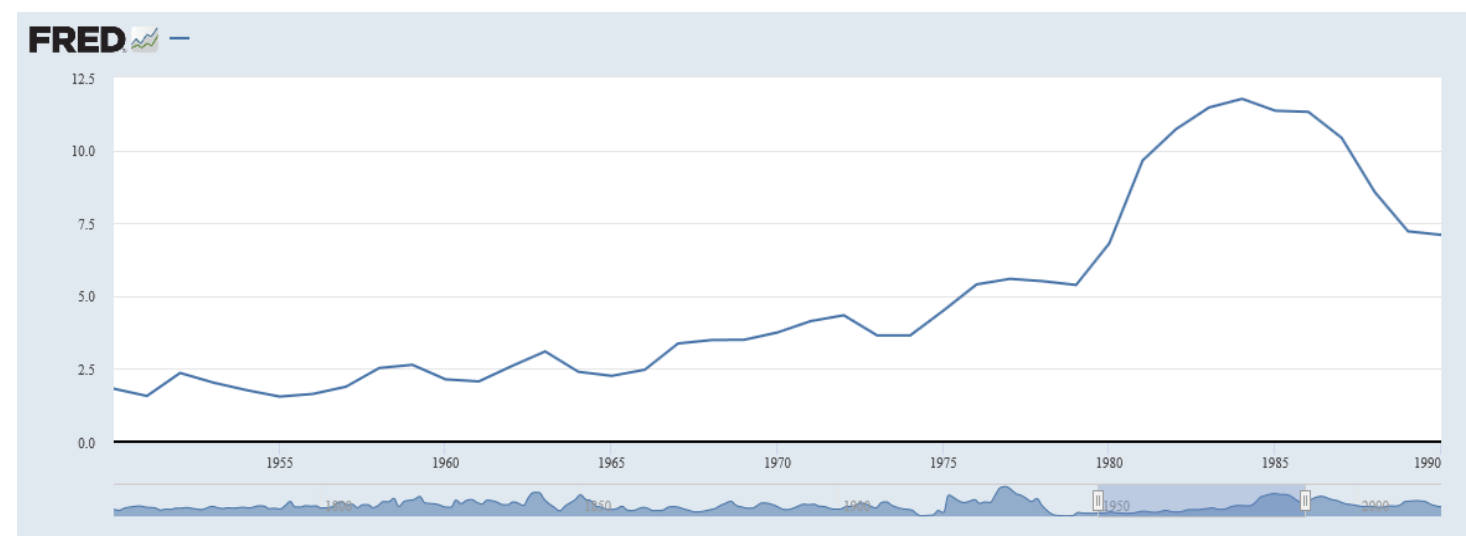

Fig. 2. Employment rate of United Kingdom[2]

Figure 1 and figure 2 show the fluctuation of inflation rate and employment rate of United Kingdom. From those figures above, it can be found that the inflation rate was less than 5 percent before 1968 and began to increase after 1968. It grew rapidly from 1972 to 1975 and reached the peak at 1975, nearly 25 percent of increase. The employment rate also increased constantly and it was more than 5 percent in 1979. However, in mid-seventies, United Kingdom was struggling in stagflation.

The core theory of Keynesian policies is to expand government spending to stimulate the stagnant economy. Keynesian policies advocated government intervention in the economy. But at that time, many stated-owned enterprises were lack of vitality because government intervened and controlled too much. High costs and inefficiency made enterprises face heavy loss. Its traditional industries, including coal, iron, steel, railway and shipbuilding, had become increasingly uncompetitive in global markets. Furthermore, its public welfare services which were built upon the legacy of Keynesian economics, were judged by people in the 1960s that the policies have become highly inefficient and were in need of urgent reform. Product stagnation, unemployment and inflation made reform in all those areas inevitable.

People found that expanding government spending to oppose recession became useless. Excessive expenses made government could not make ends meet. Because Keynesian cannot solve inflation and unemployment simultaneously. And actually, people thought that the excessive government expenditure caused this dilemma and made it much worse. So they said that treatment was worse than disease.

At the time when Margaret Thatcher became the prime minister in May 1979, Britain had entered a period of sustained economic stagnation and industrial decline. Britain endured a recession in the 1970s. In all these areas reform was inevitable. However, the decision had to be made on how to carry out the reform and whether the social casualties of industrial change would be protected.

After Thatcher won the 1979 general election, she became Britain's first female prime minister. However, it was not very long before she began to make her marks domestically with a strong monetarism policy to manage the national economy. She believed that monetarism policy is the only way to save Britain from stagflation. So she made the monetary policies based on monetarism and took inflation as the priority to be solved. The monetarism theory indicates that every private sector has stability. It tends to have their own inherent unemployment rate and output. Any increasing of nominal income that beyond real income will be expressed as price increasing.

So the key of economic recovery and unemployment decline is to decrease inflation.

\section{Analysis on Monetarism}

Monetarism appeared in 1950s. Professor Milton Friedman, who came from Chicago University, was one typical example of monetarism economist. Friedman was famous for his well-known saying, "Inflation is always and everywhere a monetary phenomenon[3]." Since the 1960s, inflation of the United States has become worse and worse. Particularly in 1973 and 1974, western 
developed countries were facing stagflation, including both high inflation rate and high unemployment rate. Keynesian theory cannot solve the dilemma. So monetarism became popular in those countries. And here are the base theory of monetarism.

\subsection{Basic theory of monetarism}

It is a theory argues that there is causality between change of quantity of money and change of prices of goods and services.

The equation of quantity theory of money are as follows:

Fisher equation: $\mathrm{M} \cdot \mathrm{V}=\mathrm{P} \cdot \mathrm{T}, \mathrm{P}$ depends on combined action of three variable, $\mathrm{M}, \mathrm{V}, \mathrm{T}[4]$.

$\mathrm{M}$ means quantity of money circulation.

$\mathrm{V}$ means velocity of money circulation.

T means aggregating quantity of gross national product.

$P$ means average prices of goods and services.

$\mathrm{V}$ and $\mathrm{T}$ usually depend on the whole society and they can be thought as constant. So the change of $\mathrm{M}$ will lead to proportional $\mathrm{P}$ change.

Cambridge equation: $\mathrm{M}=\mathrm{K} \cdot \mathrm{P} \cdot \mathrm{Y}$

$M$ means quantity of money.

$P$ means prices of goods and services.

Y means real income.

$\mathrm{P} \cdot \mathrm{Y}$ means nominal income.

$\mathrm{K}$ is the ratio of quantity of money and nominal income.

Assuming that $\mathrm{K}$ and $\mathrm{Y}$ are constant, it can be found that $\mathrm{P}$ depends on the quantity of money. When the quantity of money increases, for example, when the government issues too much currency, the prices of goods and services will grow proportionally, which indicates inflation.

\subsection{Natural rate of unemployment}

Monetarism economists believe there is a natural rate of unemployment. It is a rate that the economy is in a normal condition. It is a non-accelerating inflation rate of unemployment. Because of Keynesian polices, government used full employment policies. After Great Depression, people feared more about unemployment rather than inflation. In order to fawn on electorates, government set radical full employment goals. In addition, they used ways such as increasing quantity of money and expanding government spending to increase the employment rate. Once there was a sign of recession, government immediately used inflation to stimulate economy. When measures to decrease inflation could not increase employment rate in a short time, government stopped those measures and used higher inflation rate to get in return of little growing of employment rate. Those actions broke the stabilization of natural rate of unemployment and led to predicament of stagflation.

\subsection{Thatcher's policies}

In the early years of the 1980s, Mrs Thatcher embarked on a policy of monetarism. This policy involved trying to target the money supply to reduce inflation. The core are higher interest rates and higher taxes and spending cuts.

In 1979, when Thatcher became the prime minster of United Kingdom, she decided to use tight monetary policies and declined money supply year after year. Besides, she declined exchange rate by buying lots of foreign exchange to decrease interest rates and encouraged investment in United Kingdom. Thatcher also cut government spending. She introduced strict immigration controls and tough policies in the aftermath of 1981 summer riots in many British cities. Another set of policies included the privatization of public utilities (gas, water, telecommunications and more controversially railways) along with welfare reform were complemented by a tough labour market activation policy. During the eleven years, among which she was the prime minister of UK, $40 \%$ state-owned enterprises of United Kingdom were transferred to privately held enterprises. 


\subsubsection{Achievements}

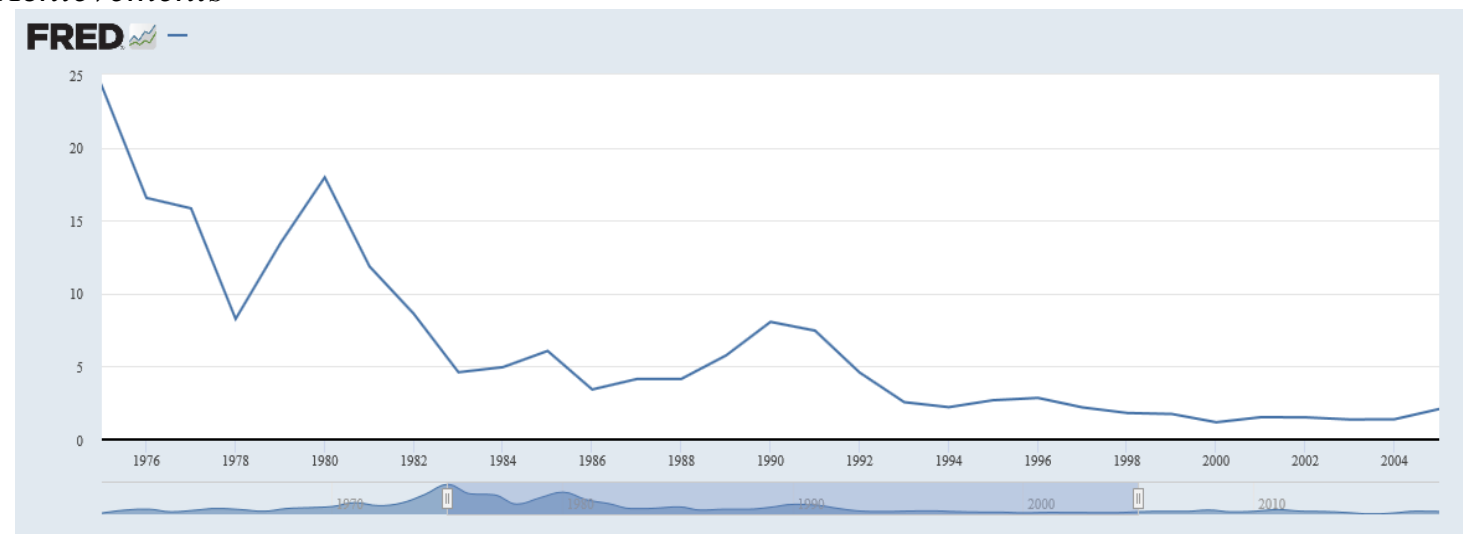

Fig. 3. The inflation rate of the United Kingdom

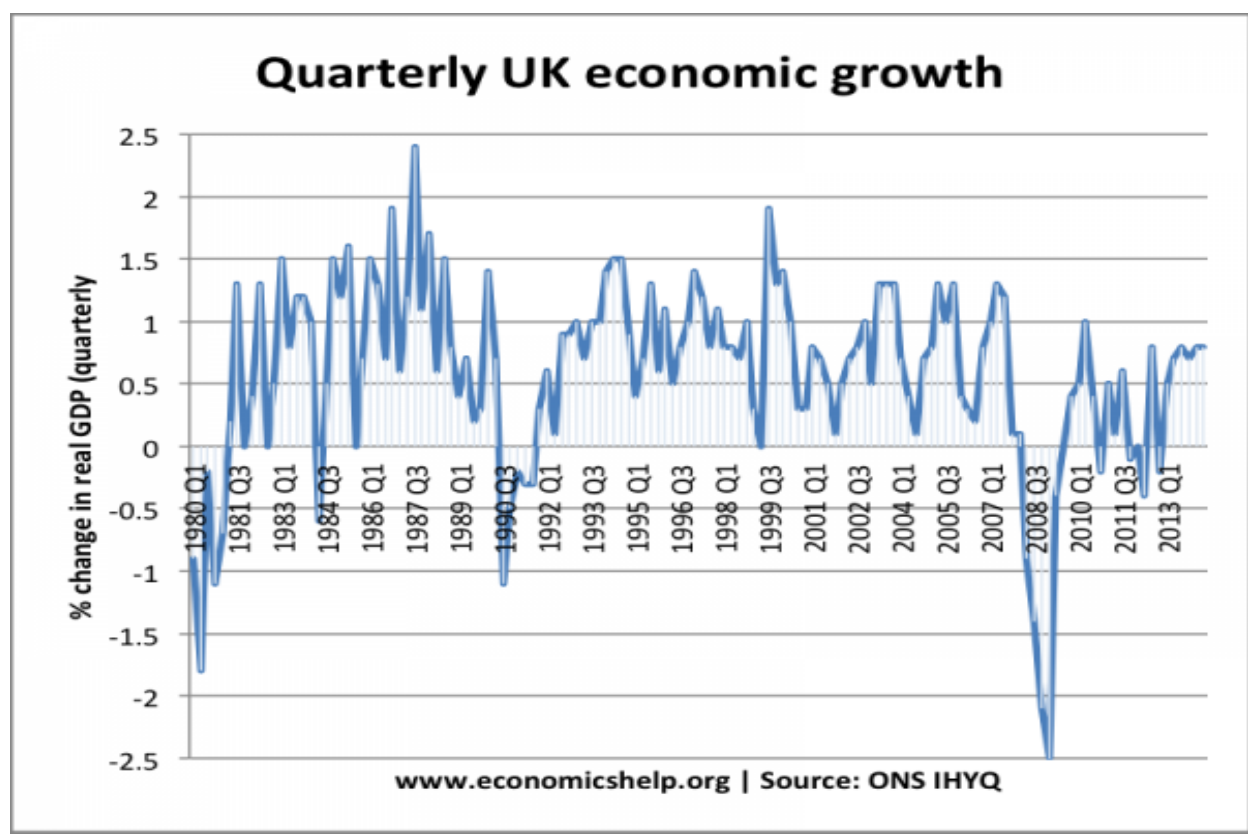

Fig. 4. The change in real GDP of the United Kingdom[5]

Figure 3 and figure 4 show the change in inflation rate and real GDP of the United Kingdom. It is undeniable that Thatcher's policies and reform made a lot of achievements and the economic growth of the United Kingdom was considerable. After recovering from 1981 recession, the UK experienced a long period of economic expansion. Toward the end of the 1980s, the growth rate reached record post-war levels (over $2 \%$ quarterly growth - equivalent to $8 \%$ monthly growth). Due to many supply-side reforms such as privatization, deregulation and reduced power of trade unions, the government believed there had been a 'supply side miracle'. The hope was that the UK could now grow at a faster rate - without inflationary pressures. The inflation rate decreased from more than $13 \%$ in 1979 to $4 \%$ in 1988.

\subsubsection{Problems}

Monetarism policies obviously made some achievements. However, the link between the money supply and inflation was much weaker than prediction made by monetarist theory.

As a result of the more regressive tax system - plus a rise in structural unemployment, there was a marked rise in inequality in the 1980s. Margaret Thatcher's policies led to widespread privatization. The US style policy and welfare reform were all policies that divided the nation and increased the gap between rich and poor. In addition to her uncompromising "school mistress" style, she showed little understanding about the lives of ordinary working people and even less empathy for the problems of the poor, created much bitterness and social division[6]. From figure 5 it can be seen that inequality of United Kingdom had rose significantly since 1982. 


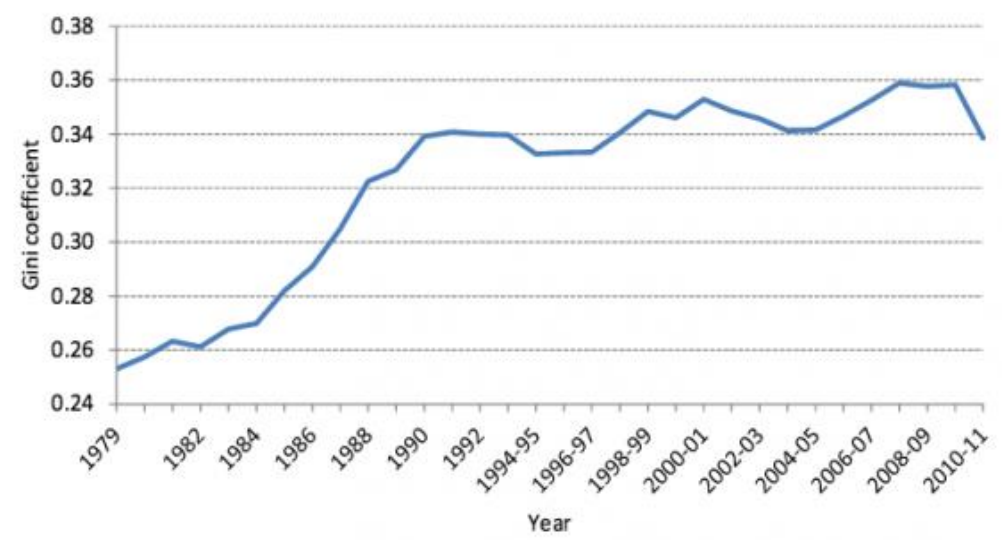

Fig. 5. Inequality as measured by Gini Coefficient[7]

Figure 6 shows the unemployment reached the unprecedented level of 3 million. Those people became victims of Thatcher's monetary policies. There was a widespread criticism of the government. In 1981, in a famous letter to the Times, 365 economists signed a letter calling on the British government to alter its economic policy.



Fig. 6. Unemployment rate of the United Kingdom

\section{Discussion}

Every macro economic policy impacts macro economy by influencing aggregate demand or aggregate supply. The effectiveness of monetary policies depends on the conditions of aggregate demand and aggregate supply. On the aggregate demand side, monetarism policies have shifted aggregate demand curve successfully. Under some special conditions, for instance, in Great Depression, people lost their belief not only to banks but also to the whole economy, so even expanding monetary policies had little promotion to the shifting of aggregate demand. Therefore we can find that the success of monetary polices needs a proper condition. However, on the aggregate supply side, the shape of aggregate supply curve will determinate effectiveness of monetary policies. When aggregate supply curve is flat, using monetary policies to shift aggregate demand curve rightward can raise employment rate and narrow the GDP gap. By contrast, if aggregate supply curve is nearly vertical, shifting aggregate demand curve rightward would only lead to inflation without output increasing, which means monetary policies will not be effective in that situation.

Undoubtedly, Thatcher's reform benefit United Kingdom a lot, but we shouldn't forget that it will not happen without perseverance to reform proposed by Thatcher. There is not a reform existing without redistribution and pain. It will inevitably bring negative influence to some people, and those people who lost their profit tend to oppose the reform. However, reform may still be necessary. Nowadays when there are reforms, Thatcher's courage and perseverance may be helpful 
to our politicians. In infrastructure fields, like iron and steel or railway, Chinese economy is facing serious surplus, so Chinese government is calling on supply-side reform. And the growing rate of Chinese GDP had slowed, so the economy stability is a more important goal than economy growing. Thatcher's policies caused high unemployment and threatened social stability, so it cannot be used directly in China.

\section{Conclusion}

Monetarism helped Britain a lot over the period of Mrs Thatcher. But there were also problems that were uncovered during this practice. The link between money supply and inflation should be reconsidered. Inflation was reduced, but it could have been done with much less pain. In seeking the measurements to meet spurious money supply targets, Thatcher's policy caused an unprecedented level of unemployment. This unemployment caused not only personal loss but also widespread social problems. However, Thatcher's personal and political toughness earned respect from both her friends and opponents over 10 years. What those policies will lead under current conditions is still uncertain, so it can be studied more from this perspective in the future.

\section{Acknowledgement}

First and foremost, I would like to show my deepest gratitude to my teachers and professors in my university, who have provided me with valuable guidance in every stage of the writing of this thesis. Further, I would like to thank all my friends and roommates for their encouragement and support. Without all their enlightening instruction and impressive kindness, I could not have completed my thesis.

\section{References}

[1] Bank of England, Consumer Price Inflation in the United Kingdom [CPIIUKA], retrieved from FRED, Federal Reserve Bank of St. Louis, [Online] Available: https://fred.stlouisfed.org/series/CPIIUKA [Accessed on December 9, 2019].

[2] Bank of England, Unemployment Rate in the United Kingdom [UNRTUKA], retrieved from FRED, Federal Reserve Bank of St. Louis, [Online] Available: https://fred.stlouisfed.org/series/UNRTUKA [Accessed on December 9, 2019].

[3] B. Y. Zhu, Cherish the memory of founder of monetarism theories-Milton Friedman, [Online]. Available:https://www.360kuai.com/pc/9af7bf7445174101c?cota=4\&kuai_so=1\&tj_url=so_rec \&sign=360_57c3bbd1\&refer_scene=so_1[Accessed on November 28, 2019].

[4]N. Gregory Mankiw, Essentials Of Economics. Beijing, Peking University Press, 2017.

[5] Organization for Economic Co-operation and Development, Constant Price Gross Domestic Product in United Kingdom [GBRGDPRQPSMEI], retrieved from FRED, Federal Reserve Bank of St. Louis, [Online] Available: https://fred.stlouisfed.org/series/GBRGDPRQPSMEI [Accessed on December 10, 2019].

[6] P. Stepney, The Legacy of Margaret Thatcher-A Critical Assessment. Open Journal of Social Sciences, vol. 2, pp.134-143, 2014.

[7] World Bank, GINI Index for the United Kingdom [SIPOVGINIGBR], retrieved from FRED, Federal Reserve Bank of St. Louis, [Online] Available: https://fred.stlouisfed.org/series/SIPOVGINIGBR [Accessed on December 10, 2019]. 